\title{
RELATIVE SUSCEPTIBILITY OF WOODY LANDSCAPE PLANTS TO JAPANESE BEETLE (COLEOPTERA: SCARABAEIDAE)
}

\author{
By David W. Held
}

\begin{abstract}
The Japanese beetle (Popillia japonica Newman) was introduced to a New Jersey nursery in 1916 and continues to spread across the United States and Canada. Adults attack foliage, flowers, and fruit of more than 300 species of plants; however, some plants are notably resistant. This paper summarizes data on plant susceptibility of woody plants to Japanese beetles collected from observations and controlled experiments. Resistance to Japanese beetle has been documented among species of maples (Acer) and birch (Betula) and among cultivars of crabapple (Malus), crapemyrtle (Lagerstroemia), and linden (Tilia). Production of certain plant odors, presence of secondary compounds in leaves, and leaf pubescence are factors affecting resistance to this insect. Host plant resistance is the most sustainable means of managing feeding damage or plant losses resulting from Japanese beetle adults. When suitable, incorporating Japanese beetle-resistant plants into new landscapes can reduce or eliminate the expense of replacing damaged plants or frequent insecticide applications.

Key Words. Popillia japonica; Japanese beetle; integrated pest management; host plant resistance.
\end{abstract}

The Japanese beetle (Popillia japonica Newman) is one of the most damaging pests of urban landscapes in the eastern United States. Yearly costs for management and mitigation of damage are estimated at US $\$ 500$ million (USDA/APHIS 2002). This scarab was introduced in 1916 to the eastern United States in infested nursery stock (Fleming 1972). At that time, entomologists were unaware of the pernicious nature of this species as evidenced from this quote, "While inspecting a nursery in southern New Jersey during August 1916, our attention was attracted by a scarabaeid feeding on the tips of Crataegus.... Inasmuch as it was assumed to be a southern species, no particular attention to it was paid at that time" (Dickerson and Weiss 1918). In the presence of abundant grass and pasture land, and the apparent absence of natural enemies, the Japanese beetle flourished. Currently, this immigrant species partially infests or is established in all states east of the Mississippi River except Florida, and its range extends north into Canada (NAPIS 2003).

Adult Japanese beetles are broadly oval, 8 to $11 \mathrm{~mm}$ (about 0.5 in.) long, metallic green in color and have coppery-brown wing covers. Larvae are typical white grubs, $\mathrm{C}$-shaped and cream colored, with three pairs of legs and a light-brown head capsule (Fleming 1972). Japanese beetle has a 1-year life cycle, spending most of its life underground as a grub. A small grub, about $1.5 \mathrm{~mm}$ (0.06 in.) long, emerges from an egg laid 3 to $5 \mathrm{~cm}$ ( 1 to 2 in.) deep into moist soil, typically under turfgrass. Females alternate between periods of feeding and mating on host plants and oviposition. During her lifetime, a female will have 12 or more egg-laying bouts and produce 40 to 60 eggs. Once hatched, grubs feed on roots and will reach full size, about $32 \mathrm{~mm}$ (1.25 in.) long, by late summer (Fleming 1972). Management of grubs is accomplished with soil insecticides applied preventively (e.g., Merit or Mach2) before egg hatch, or curatively (e.g., Dylox or Sevin) after small grubs are present. Presence of grubs or grub damage may be associated with nearby plants infested with adults; however, females will disperse to find a suitable site for oviposition (Fleming 1972; Potter and Held 2002).

Japanese beetle adults are active from June through August in most of its geographic range. These beetles are day active and mate and feed concurrently on host plants. They can defoliate more than 300 species of woody and herbaceous plants in 79 plant families (Fleming 1972; Potter and Held 2002). Because of their mobility and gregarious habits, swarms of Japanese beetle continually infest and defoliate new plants during the growing season. These factors can complicate control of adults, especially when using short-residual insecticides such as pyrethroids. Certain systemic products delivered through soil or trunk injection are available for control of Japanese beetles on mature, established street and residential trees; however, that treatment may not be an option for newly installed landscape plantings.

Use of insecticides to manage Japanese beetle can be reduced if resistant plants are substituted for more susceptible ones in commercial and residential landscapes. Observations and controlled experiments indicate that certain plant species, and even cultivars of the same species, vary in susceptibility. For example, moderate or complete resistance to Japanese beetle feeding is documented for most evergreens, certain crabapples (Malus), lindens (Tilia), maples (Acer), birch (Betula), and crapemyrtles (Lagerstroemia) (Fleming 1972; Ranney and Walgenbach 
1992; Spicer et al. 1995; Potter et al. 1998; Miller and Ware 1999; Pettis et al. 2004). There is no resistance to Japanese beetle among species or cultivars of rose (Rosa) (Potter et al. 1998; Held and Potter 2004).

Most of the information on host susceptibility to Japanese beetle originated from a landmark survey summarized by W.E. Fleming (1972). This publication has since gone out of print; however, the information remains relevant to urban horticulture because of the continued spread of Japanese beetles into the United States and Canada. In his review, Fleming (1972) established a damage rating system based on observations of plant damage noted for each plant species in his listing. This rating system is qualitative and assigns a relative rank to each species based on written and oral accounts of Japanese beetle feeding damage noted from 1920 through 1963, primarily in the New England area (Fleming 1972).

Additional laboratory and field evaluations of Japanese beetle susceptibility for certain horticulturally important taxa have been further investigated by contemporaries of Fleming. These subsequent studies compared the percentage of defoliation of field- or container-grown plants in a common garden type of experiment (e.g., Potter et al. 1998). Blocks of woody plants representing replicates of each cultivar or species were subject to defoliation by natural beetle populations during one or more years. Additional laboratory or controlled field experiments were also used to verify the results of field tests for crabapple (Ranney and Walgenbach 1992; Spicer et al. 1995), crapemyrtle (Pettis et al. 2004), and linden (Miller and Ware 1999). Besides the field observations on Ulmus procera, U. rubra, and U. americana in Fleming (1972), susceptibility of elm species is based on laboratory experiments with detached leaves or defoliation of plants caged with beetles (Miller et al. 2001). Discrepancies in seasonal results from multi-year field evaluations have been noted and are attributed to the relative abundance of adults from year to year (Fleming 1972; Potter et al. 1998).

The purpose of this paper is to provide landscape architects, professional landscape managers, and arborists a comprehensive list of woody plants and their relative susceptibility to Japanese beetle. Although the results of these resistance screenings were reported in scientific or extension publications, there has been no single source of host plant data for Japanese beetle since Fleming (1972). This paper has compiled the data from Fleming (1972) and amended it with data from recent experiments to produce a comprehensive record of plant susceptibility to Japanese beetle.

\section{DESCRIPTION OF DATA PRESENTATION}

Data are presented in table form, alphabetically by family, then scientific name. Tables 1 and 4 use a rating to indicate susceptibility. This rating is an adaptation of the system used by Fleming (1972). When a plant is designated "resistant," it means observed plants were either never fed on or rarely fed on by Japanese beetles. "*” and "**" indicate plants on which feeding has been observed but is either occasional or light, respectively. "***" and "****" indicate plants that are commonly fed on by Japanese beetle, resulting in either moderate or extensive feeding damage, respectively. Plants with the latter two ratings will likely sustain considerable feeding damage or be completely defoliated if Japanese beetles are present.

Qualitative ratings for Prunus serrulata, P. serotina, and $P$. virginiana came from Fleming (1972), whereas all others were adapted from field defoliation data (Ranney and Walgenbach 1992). In the only field study with birch (Betula) species and cultivars, defoliation was $1 \%$ or less for all nine taxa, except for Himalayan birch (B. jacquemontii), which was 16\% (Ranney and Walgenbach 1992). Based on these data, most birch are not preferred hosts (Table 1), except for Himalayan, European white, and gray, of which the latter two were ranked as more susceptible by Fleming (1972).

Tables 2 and 3 summarize resistance among cultivars of crapemyrtles and crabapples from field and laboratory experiments. Susceptibility ratings for crapemyrtle varieties are adapted from susceptibility rankings assigned by Pettis et al. (2004). The qualitative ratings assigned to crabapple cultivars (Table 3) were derived from three evaluations conducted in North Carolina (Ranney and Walgenbach 1992) and Kentucky (Spicer et al 1995; Potter et al. 1998). Relative susceptibility of the 26 cultivars common to both sites was similar (Potter et al. 1998).

Crapemyrtle and crabapple species or cultivars are listed under headings indicating their relative susceptibility. As before, "resistant" indicates that observed plants were rarely fed on. For crabapples, only those with less than 10\% defoliation in field studies were assigned to this rating. "Moderately resistant" means that beetle feeding was observed but light. Crabapples ranked as moderately resistant generally sustained 20\% to $45 \%$ defoliation. Plants designated "moderately susceptible" will have noticeable damage by Japanese beetle corresponding to $50 \%$ to $70 \%$ defoliation for crabapple varieties. All plants considered "susceptible" will be extensively damaged or completely defoliated by Japanese beetle, equivalent to about 75\% to $100 \%$ defoliation in the crabapple field studies (Ranney and Walgenbach 1992; Spicer et al 1995; Potter et al. 1998).

Ratings for linden taxa (Table 4) were taken from observations in Fleming (1972), a 3-year field study of eight Tilia spp. in Kentucky (Potter et al. 1998), and Miller and Ware (1999), which combined laboratory feeding assays with leaves or leaf discs, with field defoliation data of 16 genotypes in Illinois. Ratings of linden were determined based on both studies; however, field defoliation data were used over laboratory results if there was any inconsistency between the relative rankings of the same variety. 
Table 1. Relative susceptibility of deciduous and evergreen woody trees and shrubs to Japanese beetles.

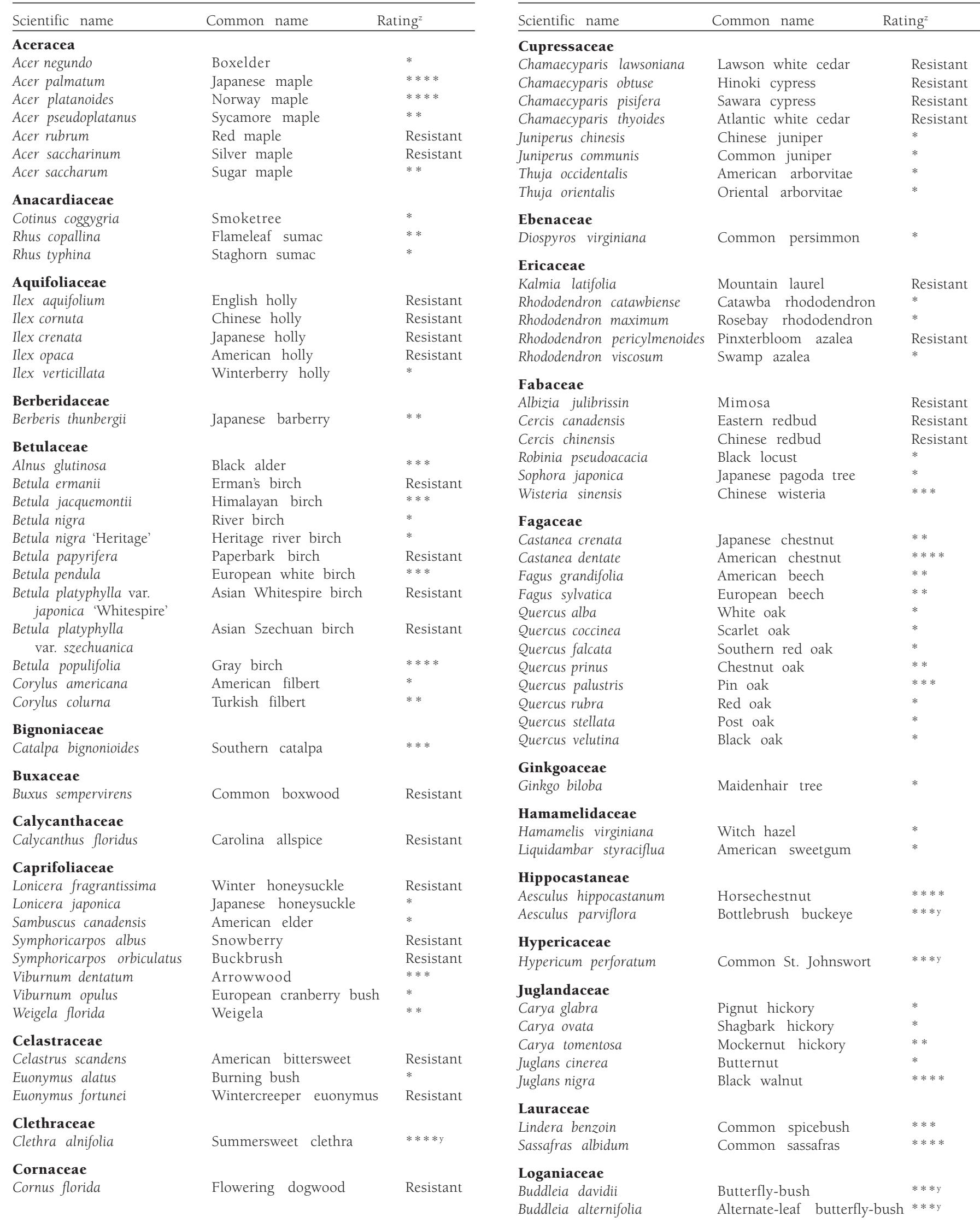


Table 1. Relative susceptibility of deciduous and evergreen woody trees and shrubs to Japanese beetles.

\section{Scientific name \\ Lythraceae \\ Lagerstroemia (see Table 2) \\ Magnoliaceae \\ Liriodendron tulipifera \\ Magnolia grandiflora \\ Magnolia $\times$ soulangiana \\ Magnolia virginiana}

Common name

Rating $^{2}$

Moraceae

Ficus carica

Ficus elastica

Morus rubra

Musaceae

Musa $\times$ paradisiacal

Myricaceae

Myrica pensylvanica

Nyssaceae

Nyssa sylvatica

Oleaceae

Forsythia $\times$ intermedia

Forsythia suspena var. sieboldii Weeping forsythia

Fraxinus americana

Fraxinus pennsylvanica

Ligustrum ovalifolium

Ligustrum vulgare

Syringa $\times$ persica

Syringa vulgaris

\section{Crapemyrtle \\ Southern magnolia \\ Saucer magnolia \\ Sweetbay magnolia}

$* * * y$
Resistant
$* y$
Resistant
Resistant
Resistant
$*$
Resistant
$*$
$*$
$*$

Common fig

Indian rubbertree

Red mulberry

French plantain

Northern bayberry

Tupelo

\section{Pinaceae}

Abies concolor

Larix deciduas

Picea abies

Picea orientalis

Pinus sylvestris

Pinus virginiana

Pseudotsuga menziesii

Tsuga canadensis

\section{Platanaceae}

Platanus $\times$ acerifolia

Platanus occidentalis

\section{Rosaceae}

Chaenomeles japonica

Crateagus laevigata

Crateagus monogyna

Exochorda racemosa

Malus (see Table 3)

Prunus $\times$ cistena

Prunus sargentii

Prunus serotina

Prunus serrulata

Prunus serrulata 'Kwanzan'

Prunus serrulata 'Mt. Fuji'

Prunus serrulata 'Tai Haku'

Prunus subhirtella

Prunus virginiana

Prunus $\times$ incamp 'Okame'

Prunus $\times$ yedoensis 'Afterglow'

Prunus $\times$ yedoensis 'Akebono'

Pyracantha coccinea

Pseudocydonia sinensis

Pyrus communis
White ash

Green ash

California privet

Common privet

Persian lilac

Common lilac

Balsam fir

European larch

Norway spruce

Oriental spruce

Scotch pine

Virginia pine

Douglasfir

Hemlock

London planetree

American planetree

Resistant

Resistant

Resistant

**

$*$

Resistant

Resistant

Resistant

$* * *$

Resistant

Resistant

Resistant

*

Resistant

Resistant

$* * * *$

$* * *$

Japanese flowering quince

English hawthorn

Common pearlbush

Purpleleaf sandcherry

Sargent cherry

Black cherry

Oriental cherry

Kwanzan oriental cherry

Mt. Fuji oriental cherry

Tai Haku oriental cherry

'Autumnalis Rosea'

Common chokecherry

Okame cherry

Afterglow Yoshino cherry

Akebono Yoshino cherry

Firethorn

Chinese quince

Pear

$* * * *$

$* *$

$* * * *$

$* * *$

$* * *$

$* * *$

$*$
Singleseed hawthorn

\begin{tabular}{l} 
Scientific name \\
\hline Rosa spp. and hybrids \\
Sorbus americana \\
Spiraea trilobata \\
Spiraea $\times$ vanhoutei \\
Rubiaceae \\
Cephalanthus occidentalis \\
Gardenia jasminoides
\end{tabular}

.

Common name
Roses
American mountain as
Three-lobed spirea
Vanhoutte spirea
Buttonbush
Gardenia
Sweet orange
White poplar
Bolleana poplar
Lombardy poplar
Babylon weeping willow
Pussy willow
Deutzia
Smooth hydrangea
Panicle hydrangea
Climbing hydrangea
Mockorange

Rating

$* * * * y$

$* * * *$

$* *$

$* *$

Rutaceae

Citrus sinensis

Salicaceae

$* * * \mathrm{y}$

Resistant

Populus alba

Populus alba pyramidalis

Populus nigra italica

Salix babylonica

Salix discolor

\section{Saxifragaceae}

Deutzia gracilis

Hydrangea arborescens

Hydrangea paniculata

Hydrangea petiolaris

Philadelphus coronaries

Mockorange

Simaroubaceae

Ailanthus altissima

Tree of Heaven

Staphyleaceae

Staphylea trifolia

Styracaceae

Halesia tetraptera

Taxaceae

Taxus baccata

Taxus brevifolia

Taxus canadensis

Taxus cuspidate

Taxodiaceae

Cryptomeria japonica

Taxodium distichum

Tiliaceae (see Table 4)

Ulmaceae

Ulmus americana

Ulmus changii

Ulmus lanceaefolia

Ulmus procera

Ulmus prunifolia

Ulmus pseudopropinqua

Ulmus rubra

Ulmus taihangshanensis

Ulmus wallichiana

American bladdernut

Resistant

Carolina silverbell

$* * *$

English yew

Resistant

Western yew

Canada yew

Japanese yew

Resistant

Resistant

Resistant

Cryptomeria

Baldcypress

*

Verbenaceae

Callicarpa dichotoma

Lantana camara
American elm

English elm

Slippery elm

Purple beautyberry

Lantana
Resistant

Resistant

$* * *$

$* * * *$

$* * \mathrm{y}$

Resistant

Resistant

"Plants designated "resistant" are never fed on or rarely fed on by Japanese beetles. "*" and "**" indicate plants on which feeding has been observed but is either occasional or light, respectively. "***" and “****" indicate plants that are commonly fed on by Japanese beetle, resulting in either moderate or extensive feeding damage, respectively.

'Flowers of these species are also fed on by Japanese beetles.
$* * * *$

$* * * *$

$* * *$

$* * * *$

$* * *$

$* *$

$* * * *$

$* * * *$

Resistant Resistant 
Table 2. Relative susceptibility of crapemyrtles to Japanese beetles.

\begin{tabular}{lll}
\hline $\begin{array}{l}\text { Resistant } \\
\text { 'Acoma' }\end{array}$ & & \\
Moderately resistant & & \\
'Biloxi' & & \\
'Catawba' & 'Cordon Bleu' & 'Potomac' \\
'Chicksaw' & 'Lipan' & 'Sioux' \\
'Choctaw' & 'Muskogee' & 'Tuskegee' \\
'Comanche' & 'Osage' & \\
& 'Pink Velour' & \\
$\begin{array}{l}\text { Moderately susceptible' } \\
\text { 'Apalachee' }\end{array}$ & \\
'Byers Standard Red' & 'Hope' & \\
'Byers Wonderful White' & 'Miami' & 'Seminole' \\
'Carolina Beauty' & 'Natchez' & 'Tonto' \\
'Centennial' & 'Ozark Springs' & 'Tuscarora' \\
'Centennial Spirit' & 'Pecos' & 'Victor' \\
'Dynamite' & 'Powhatan' & 'Worlliam Toovey' \\
'Hardy Lavender' & 'Raspberry Sundae' & 'Yuma' \\
$\begin{array}{l}\text { Susceptible } \\
\text { 'Red Rocket' }\end{array}$ & & \\
\hline
\end{tabular}

Table 3. Relative susceptibility of crabapples to Japanese beetles.

\section{Resistant}

Malus baccata Jackii

Malus hupehensis

'Golden Raindrops'

Moderately resistant

'Adirondack'

'Baskatong'

'Bob White'

'Brandywine'

'Callaway'

'Centurion'

'Christmas Holly'

'David'

'Doubloons'

'Gem'

'Edna Mullins'

\section{Moderately susceptible}

'Adams'

'Beverly'

'Candymint Sargent'

'Coralburst'

'Donald Wyman'

Malus floribunda

'Henningii'

\section{Susceptible}

Malus baccata

'Dolgo'

'Hopa'
'Harvest Gold'

'Jewelberry'

'Louisa'

Malus halliana var. parkmanii 'Red Jewel'

Malus tschonoski

'Madonna'

'Molten Lava'

'Naragansett'

'Ormiston Roy'

'Professor Sprenger'

'Profusion'

'Ralph Shay'

'Red Jade'

'Indian Magic'

'Indian Summer'

'Mary Potter'

'Pink Princess'

'Purple Prince'

'Red Baron'

'Robinson'

'Liset'
'Radiant'
'Red Splendor'

'Liset'

'Red Splendor'
'Strawberry Parfait'

Malus sargentii

'Sentinel'

'Silver Moon'

'Snowdrift'

'Sugar Tyme'

'Wintergold'

Malus $\times$ zumi 'Calocarpa'

Malus $\times$ zumi 'Winter'

'Ruby Luster'

'Selkirk'

'Sinai Fire'

'Snow Magic'

'Tina'

'White Angel'

'Royalty'

'Velvet Pillar'

'Weeping Candied Apple' 


\section{Table 4. Relative susceptibility of lindens to Japanese beetles evaluated in laboratory or field experiments.}

\begin{tabular}{|c|c|c|}
\hline Scientific name & Common name/cultivar & Rating ${ }^{z}$ \\
\hline Tilia amurensis & & $* *$ \\
\hline Tilia americana & & $*$ \\
\hline \multirow[t]{2}{*}{ Tilia americana } & 'Legend' & $* *$ \\
\hline & 'Redmond' & $* * *$ \\
\hline Tilia caroliniana & & $*$ \\
\hline Tilia chinesis & & $* *$ \\
\hline \multirow[t]{6}{*}{ Tilia cordata } & ‘Chancellor' & $* * *$ \\
\hline & 'Fairview' & $* *$ \\
\hline & 'Glenleven' & $* *$ \\
\hline & 'Greenspire' & $* * * *$ \\
\hline & 'Olympic' & $* * * *$ \\
\hline & 'Prestige' & $* * *$ \\
\hline Tilia $\times$ euchlora & & $* * *$ \\
\hline Tilia heterophylla & 'Continental Appeal' & $* *$ \\
\hline Tilia japonica & & $*$ \\
\hline Tilia maximowicziana & & $* *$ \\
\hline Tilia mongolica & & $* *$ \\
\hline Tilia oliveri & & $*$ \\
\hline Tilia orbicularis & & $* * *$ \\
\hline Tilia petiolaris & Pendent silver linden & $*$ \\
\hline Tilia platyphyllos & Largeleaf linden & $* * *$ \\
\hline Tilia platyphyllos & 'Parade' & $*$ \\
\hline Tilia tomentosa & & $* *$ \\
\hline Tilia tomentosa & 'Erecta' & $* *$ \\
\hline Tilia tomentosa & 'Sterling' & $* *$ \\
\hline Tilia sp. & 'Sundance' & $*$ \\
\hline
\end{tabular}

\section{DISCUSSION}

Susceptibility of plants to Japanese beetle should be one factor, among many, considered when selecting plants, particularly long-lived woody plants, for residential and commercial landscapes. Resistance of one plant species to Japanese beetle does not necessarily imply resistance to other plant-feeding insects or plant pathogens (Smitley and Peterson 1993; Pettis et al. 2004). For example, the crapemyrtle varieties 'Tonto' and 'Tuscarora' are moderately susceptible to Japanese beetle, but the same varieties are resistant to metallic flea beetles (Altica spp.), an important pest of crapemyrtle in production (Pettis et al. 2004).

Resistance of woody host plants to Japanese beetle is probably mediated by the presence or absence of deterrent compounds found in the foliage (Keathley et al. 1999; Potter and Held 2002). Control products containing certain plant extracts, such as neem (azadirachtin), can effectively deter feeding in laboratory choice tests (Ladd et al. 1978; Held et al. 2001) but often fail to provide similar protection when tested on whole plants in the field (Harper and Potter 1994; Witt et al. 1999). Abundant field populations, however, will reduce the efficacy of both conventional and botanical insecticides because of additional adults re-infesting treated plants.

Elms and lindens are considered preferred hosts for the Japanese beetle. Among elms, only U. lancefolia and U. prunifolia were slightly less susceptible than the other species (Miller et al. 2001). Although no lindens are resistant, varieties such as 'Parade', 'Legend', and 'Sterling' appear to be less susceptible (Potter et al. 1998). Moderate to dense leaf pubescence may be an important factor in susceptibility of linden and elm to Japanese beetle. For example, foliage of T. platyphyllos 'Parade', T. tomentosa 'Sterling', and U. lamellose have heavy pubescence and is less preferred by Japanese beetle (Potter et al. 1998; Miller and Ware 1999; Miller et al. 2001). Conversely, certain plants, such as species of Ilex and Rhododendron, with waxy or glossy foliage are also resistant to Japanese beetle (Fleming 1972; Keathley et al. 1999).

Plants with purplish or deep red foliage (e.g., 'Crimson King' Norway maple) are often observed to sustain more damage by Japanese beetle than green-leaved cultivars (Rowe et al. 2002). Foliage color alone, however, does not account for these differences. When two artificial ficus trees with foliage painted either green or purple are placed side by side in the field, significantly more beetles land on the green-leaved plants (Rowe et al. 2002). Flower color, however, does influence susceptibility of flowering plants to Japanese beetle. Rose varieties with yellow or white flowers are more likely to be attacked than those with darkercolored blooms (Held and Potter 2004).

Resistance of certain plants to Japanese beetle also depends on the production of attractive volatile compounds following damage by Japanese beetle or other plant-feeding insects (Loughrin et al. 1995). Japanese beetles use a wide range of floral and fruitlike compounds to locate a host plant (Fleming 1972; Loughrin et al. 1995, 1996). Laboratory tests show that Japanese beetle often cannot discriminate among foliage of plants that differ in susceptibility in the field (Loughrin et al. 1995, 1996). This finding indicates that Japanese beetles are attracted to plants regardless of their status as a host (Potter and Held 2002). However, if susceptible plants suffer feeding damage, they produce an array of attractive volatiles that serve as aggregation stimulants for Japanese beetle (Loughrin et al. 1995, 1996). Therefore, a susceptible plant in the field may not be inherently more attractive, but, if damaged, these plants produce the volatiles that recruit Japanese beetles much like sharks attracted to a blood trail in the water.

Host plant resistance is the most sustainable means of managing feeding damage or plant losses resulting from Japanese beetle adults. Landscape designers in states on the front of this insect's range expansion should consider incorporating resistant plants into residential, commercial, and municipal landscapes as well as any other long-term 
plantings. This approach can reduce the economic and environmental costs associated with the repeated use of insecticides to prevent or reduce damage to urban landscapes in the future.

\section{LITERATURE CITED}

Dickerson, E.L., and H.B. Weiss. 1918. Popular and practical entomology. Can. Entomol. 7:217-221.

Fleming, W.E. 1972. Biology of the Japanese beetle. Technical Bulletin 1449 of the United States Department of Agriculture. Washington, DC. 129 pp.

Harper, C., and D.A. Potter. 1994. Deterrence of neembased insecticides to Japanese beetles in six preferred host plants. Proc. S. Nurs. Res. Conf. 39:60-63.

Held, D.W., and D.A. Potter. 2004. Floral characteristics influence susceptibility of hybrid tea roses (Rosa $\times$ hybrida) to Japanese beetles. J. Econ. Entomol. 97:353-360.

Held, D.W., T. Eaton, and D.A. Potter. 2001. Potential for habituation to a neem-based feeding deterrent in Japanese beetles, Popillia japonica. Entomol. Exp. Appl. 101:25-32.

Keathley, C.P., D.A. Potter, and R.L. Houtz. 1999. Freezealtered palatability of Bradford pear to Japanese beetle: Evidence for decompartmentalization and enzymatic degradation of feeding deterrents. Entomol. Exp. Appl. 90:49-59.

Ladd, T.L. Jr., M. Jacobson, and C.R. Buriff. 1978. Japanese beetles: Extracts from neem tree seeds as feeding deterrents. J. Econ. Entomol. 71:810-813.

Loughrin, J.H., D.A. Potter, and T.R. Hamilton-Kemp. 1995. Volatile compounds induced by herbivory acts as aggregation kairomones for the Japanese beetle (Popillia japonica Newman). J. Chem. Ecol. 21:1457-67.

Loughrin, J.H., D.A. Potter, T.R. Hamilton-Kemp, and M.E. Byers. 1996. Volatile compounds from crabapple cultivars (Malus spp.) differing in susceptibility to the Japanese beetle (Popillia japonica Newman). J. Chem. Ecol. 22:1295-1305.

Miller, F, and G. Ware. 1999. Feeding preferences for selected Tilia spp. and cultivars by the adult Japanese beetle (Coleoptera: Scarabaeidae). J. Arboric. 25:168-173.

Miller, F., G. Ware, and J. Jackson. 2001. Preference of temperate Chinese elms (Ulmus spp.) for the adult Japanese beetle (Coleoptera: Scarabaeidae). J. Econ. Entomol. 94:445-448.

National Agricultural Pest Information Service (NAPIS). 2003. Pest Tracker Invasive Insect: Japanese Beetle, Popillia japonica. www.ceris.purdue.edu/napis/pests/jb (accessed 9/16/04).
Pettis, G.V., D.W. Boyd, Jr., S.K. Braman, and C. Pounders. 2004. Potential resistance of crape myrtle cultivars to flea beetle (Coleoptera: Chrysomelidae) and Japanese beetle (Coleoptera: Scarabaeidae) damage. J. Econ. Entomol. 97:981-992.

Potter, D.A., and D.W. Held. 2002. Biology and management of the Japanese beetle. Ann. Rev. Entomol. 47:175-205.

Potter, D.A., P.G. Spicer, D. Held, and R.E. McNiel. 1998.

Relative susceptibility of cultivars of flowering crabapples, lindens, and roses to defoliation by Japanese beetles. J. Environ. Hortic. 16:105-110.

Ranney, T.G., and J.F. Walgenbach. 1992. Feeding preferences of Japanese beetles for taxa of birch, cherry, and crabapple. J. Econ. Entomol. 88:846-854.

Rowe, W.J. II, D.A. Potter, and R.E. McNiel. 2002.

Susceptibility of purple- versus green-leaved cultivars of woody landscape plants to the Japanese beetle. HortScience 37:362-366.

Smitley, D.R., and N.C. Peterson. 1993. Evaluation of selected crabapple cultivars for insect resistance. J.

Environ. Hortic.11:171-175.

Spicer, P.G., D.A. Potter, and R.G. McNiel. 1995. Resistance of crabapple (Malus spp.) cultivars to defoliation by the Japanese beetle (Coleoptera: Scarabaeidae). J. Econ. Entomol. 88:979-985.

United States Department of Agriculture/Animal and Plant Health Inspection Service (USDA/APHIS). 2002. Managing the Japanese beetle. A Homeowner's Handbook. United States Department of Agriculture, Washington, DC. www.pueblo.gsa.gov/cic_text/housing/ japanese-beetle/jbeetle.html (accessed 9/16/04).

Witt, J.D., S.L. Warren, T.G. Ranney, and J.R. Baker. 1999. Biorational and conventional plant protectants reduce feeding by adult Japanese beetles. J. Environ. Hortic. 17:203-206.

Acknowledgments. I thank P. Knight, C. Pounders, and B. Layton (Mississippi State University) for helpful comments on an earlier draft of this manuscript. I also acknowledge the authors of the numerous field and laboratory evaluations of host plants of Japanese beetles whose careful observations provide the backbone of this review. This paper is no. J10525 of the Mississippi State Agricultural Experiment Station.

Assistant Professor of Entomology Mississippi State University

Coastal Research and Extension Center

1815 Popps Ferry Road

Biloxi, MS 39532, U.S. 
Zusammenfassung. Der japanische Käfer Popillia japonica Newman wurde 1916 in eine Baumschule in New Jersey eingeführt und breitet sich nach Norden und Osten quer durch die Vereinigeten Staaten aus. Die Erwachsenen attackieren Blätter, Blüten und Früchte von mehr als 300 Arten, dennoch sind einige resistent geblieben. Dieses Papier erfasst die Daten der für diesen Käfer anfälligen Gehölze, die aus Beobachtungen und kontrollierten Experimenten stammen. Eine Resistenz gegenüber Jap. Käfer wurde bei einigen Ahornarten, Birken, einigen Kultivaren von Malus, Lagerstroemia und Tilia dokumentiert. Die Produktion bestimmter Pflanzengerüche, Präsenz sekundärer Inhaltstoffe in den Blättern und behaarte Blätter sind Faktoren, die die Resistenz gegenüber diesem Insekt beeinflussen. Die Resistenz der Wirtspflanze ist die meistzuerhaltene Mittel um Fraßschäden oder Pflanzenverluste durch den Käfer zu managen. Wenn möglich kann die Inkorporation resistenter Pflanzen in neue Landschaften die Ausgaben für die Ersatzpflanzungen beschädigter Gehölze reduzieren und die Insektizidanwendungen minimieren.

Resumen. El escarabajo japonés, Popillia japonica Newman, fue introducido a New Jersey en 1916, y continúa esparciéndose al norte y este a través de los Estados Unidos. Los adultos atacan el follaje, flores y frutos de más de 300 especies de plantas. Sin embargo, algunas plantas son notablemente resistentes. Este reporte resume los datos sobre la susceptibilidad de plantas leñosas a los escarabajos japoneses colectados de observaciones y experimentos controlados. La resistencia al escarabajo japonés ha sido documentada entres especies de maples (Acer), abedules (Betula) y entre cultivares de manzanos (Malus), astronómicas (Lagerstroemia) y tilos (Tilia). La producción de ciertos olores por las plantas, presencia de componentes secundarios en las hojas y pubescencia de las mismas son factores que afectan la resistencia a estos insectos. La resistencia de las plantas hospederos es el medio más sustentable de manejo del daño o pérdida de plantas resultante de los escarabajos japoneses adultos. Cuando se desea, la incorporación de plantas resistentes en nuevos escenarios puede reducir o eliminar los gastos de reemplazo de plantas dañadas o las aplicaciones frecuentes de insecticidas.

Résumé. Le scolyte japonais (Popillia japonica Newman) a été introduit dans une pépinière du New Jersey en 1916 et continue depuis de s'étendre vers le nord et l'est des ÉtatsUnis. Les adultes attaquent le feuillage, les fleurs et les fruits de plus de 300 espèces de plantes, mais certaines plantes demeurent résistantes de manière notable. Cet article fait un résumé des données recueillies sur la susceptibilité des plantes ligneuses aux scolytes japonais, et ce à partir de d'observations et d'expériences contrôlées. La résistance au scolyte japonais a été documentée parmi des espèces des genres Acer, Betula et sur certains cultivars de Malus, de Lagerstroemia et de Tilia. La production de certaines odeurs par les plantes, la présence de composés secondaires dans les feuilles et la pubescence foliaire sont des facteurs qui affectent la résistance à cet insecte. La résistance de la plante hôte est le moyen le plus efficace pour gérer les dommages par causés par l'alimentation ou encore les pertes de végétaux résultants des scolytes japonais adultes. Lorsque cela est possible, l'incorporation de plants résistants au scolyte japonais dans les nouveaux aménagements peut réduire ou éliminer les dépenses pour le remplacement de végétaux endommagés ou les applications fréquentes d'insecticide. 